\title{
THE HINTON ST. MARY AND FRAMPTON MOSAICS: PROBLEMATIC IDENTIFICATIONS OF CHRISTIAN-PAGAN HYBRID IMAGERY

\author{
Shelby Colling
}

\begin{abstract}
:
Despite the frequent interpretation of any Early-Christian-era art that contains both Christian and pagan imagery as being solely Christian in meaning, this paper argues that the identification of these images as being Christian in nature, with the pagan imagery only present as borrowed ideas to support a Christian message, is problematic. By assessing some of the existing scholarship surrounding this topic, I attempt to problematize the assumptions made that lead to these widelyaccepted interpretations.
\end{abstract}


Much of the discourse surrounding imagery that appears to be a hybrid of Christianpagan imagery seems to be rooted in theological research on the history of Christianity. This discourse interprets the hybrid images as examples of pagan imagery being adapted by Christian groups as representations or allegories of their religious messages. Therefore, the existence of any pagan imagery that shares spaces with Christian imagery is interpreted as a process of the ‘Christianization’ of pre-existing and well-known pagan images. Despite this firm and absolute identification of imagery as fitting into the singular category of either "Christian" or "Pagan" in nature, the assumption that no middle ground can exist is problematic. The interpretations of the Hinton St. Mary and the Frampton mosaics, both dated to around the mid-fourth century AD, incorporate imagery of both Roman mythology and Christian figures, and until recently have been assumed to be examples of the 'Christianization' of pagan images. The images on the mosaics contain a variety of pagan deities and figures, but also depict the Chi-Rho monogram (that being a monogram of the first two letters of the ancient Greek word for 'Christ') and a figure thought to represent Christ, as well. While most scholarship regarding the contact between Christian and pagan imagery seems to focus on the Christian adoption of pagan symbols, recent interpretations of Hinton St. Mary and Frampton mosaics are less firm in their desire to be branded as either 'pagan' or 'Christian,' with scholars engaging in this topic arguing for each. Given that these mosaics are most often analyzed as a pair due to their similar combination of Christian and pagan imagery, suspected dating, close geographical location and the likelihood of being the both of the same mosaicist, ${ }^{1}$ this paper will also examine both mosaics.

To first attempt to classify any imagery, the archaeological context in which these images are found provide a foundation for which they can be interpreted. While the context in which

\footnotetext{
${ }^{1}$ Thomas, Christianity in Roman Britain, 181.
} 
these mosaics were laid would undoubtedly provide a clue to their branding as either 'pagan' or 'Christian,' sources also differ on the function of the buildings they were placed within. While the corner pavilion and end room (divided into an antechamber, main room, and apse) of Frampton were common features of Romano-British villas, archeologists Perring and Thomas argue that the layout far more resembles a small, basilica-like plan, and may not be a residential villa at all, but perhaps could have served a religious function. ${ }^{2}$ While several sources refer to the buildings as ‘villas,’ only a singular source argues for this ‘basilica-like’ format. Though Thomas' article is not necessarily incorrect, the remainder of his article continues under the assumption that the mosaics are Christian in nature with little to no attempts to problematize the interpretations. This raises the question of his conclusion of a basilica plan being reached as a result of his assumption of the mosaics within it to be Christian. Another source recognizes the differing interpretations of the floorplan but states that the layout of Hinton St. Mary is "not well understood.”3 While this argument explains the conflicting opinions of the design of the buildings, it certainly seems contrary to the confident statements within the articles themselves, which indicate no confusion or even previous debate regarding their identification. Little is said in these sources regarding additional archeological evidence found within the vicinity of the sites to suggest the usage of the buildings. This is particularly odd, as the materials found in or around the building would surely provide an indication of either villa or basilica. Perhaps nothing is mentioned because such archaeological finds were not found, but the complete lack of acknowledgement gives the impression of a neglect to address the topic. While other archaeological finds seem to be lacking, the mosaic itself contains significant imagery. In Frampton, the northern-most room featured images of the sea and Neptune, the antechamber

\footnotetext{
2 Thomas, Christianity in Roman Britain, 181-182.

${ }^{3}$ Pearce, “The Hinton St Mary Mosaic Pavement,” 196.
} 
contained a mosaic of Bacchus, and the main room featured a centre panel that depicted Bellerophon, a figure that also features in Hinton St. Mary's mosaics. ${ }^{4}$ The apse, in contrast to the depiction of the polytheistic gods throughout the rest of the mosaic, contained the Chi-Rho monogram. Therefore, while the Frampton mosaic featured far more pagan imagery than decidedly Christian imagery, the Chi-Rho was given the most prominent placement within the building. ${ }^{5}$ Similarly, the Chi-Rho monogram also appears in a central medallion on the Hinton St. Mary mosaic, the adjoining room features a prominent image of Bellerophon slaying the chimaera, framed by two panels depicting hunting scenes of hounds pursuing deer. ${ }^{6}$ But unlike the more isolated location of the Frampton Chi-Rho, the Hinton St. Mary mosaic is surrounded by three semi-circular panels depicting the same types of deer hunting scenes, one tree image, and four corner images of male busts with tousled hair that seem to represent wind gods. ${ }^{7}$ The Chi-Rho medallion itself features a male bust whose garments are consistent with other contemporary depictions of Christ, flanked by two pomegranates. ${ }^{8}$

Given the significance of the Chi-Rho monogram representing the first two Greek letters of 'Christ' and the consistency of the depiction of the bust figure with other images of Christ in the same time period, scholars identifying this central medallion as a 'Christian' image is certainly a common conclusion. However, in her article on the Hinton St. Mary mosaic, Susan Pearce challenges the assumptions that the Chi-Rho monogram automatically indicates a Christian household and the scholars' subsequent identification of the central bust as Christ. Most scholars make this assumption due to the monogram, while others delve further and

\footnotetext{
${ }^{4}$ Perring, "Gnosticism in Fourth-Century Britain,” 99-101.

${ }^{5}$ Perring, "Gnosticism," 105.

${ }^{6}$ Dunbabin, Mosaics of the Greek and Roman World, 95.

${ }^{7}$ Dunbabin, Mosaics, 95

${ }^{8}$ Scott, Art and Society in Fourth-Century Britain, 155.
} 
identify the tunica and pallium the bust wears as being typical imagery found on other figures of Christ. ${ }^{9}$ However, Pearce argues that the Christian meaning of the Chi-Rho is not necessarily indicative of the central figure of the Hinton St. Mary mosaic being Christ and that the overall medallion is not necessarily intended to acknowledge the Christian religion. In her article, she supports this claim through with mention of the cult of Constantine in Roman Britain. Becoming Emperor while he was in the North of Britain, Constantine's success in the Battle of the Milvian Bridge would bring his associations with the Chi-Rho into the imagery of the victory.

Constantine's close ties to the Chi-Rho would continue with the Roman toleration of Christian worship in AD 313. Constantine would later visit Britain in AD 312, 313/314, and 314/315, making him no stranger to Britain. ${ }^{10}$ The Chi-Rho would also continue to appear on the coinage minted for later emperors, such as Magnentius and Constantine II $^{11}$ in Figures 2 and 3, respectively. These coins, dated to around the mid-fourth century, are consistent with the dating of the mosaics found at both Frampton and Hinton St. Mary. Pearce also points out the similar facial features of the mosaic to that of the figures depicted on the coins, especially Magnentius, as shown in Figure 2, particularly the heavy-set jaw and angular nose. ${ }^{12}$ Therefore, Pearce argues that the Chi-Rho is not necessarily an indication of a Christian household displaying religiously significant imagery but perhaps a celebration of an emperor. Through Constantine, we know such emperor cults existed in Britain, and that these emperors were tied to the 'Christian' ChiRho. Coinage found from several emperors around the time that the mosaics have been dated could support this claim, as many contain the Chi-Rho held by a reverse-side figure that is often identified to be the same emperor depicted on the obverse (see Figures 2 and 3).

\footnotetext{
${ }^{9}$ Scott, Art and Society, 156.

${ }^{10}$ Pearce, The Hinton St Mary Mosaic Pavement, 194.

${ }^{11}$ Pearce, 196.

12 Pearce, 193.
} 


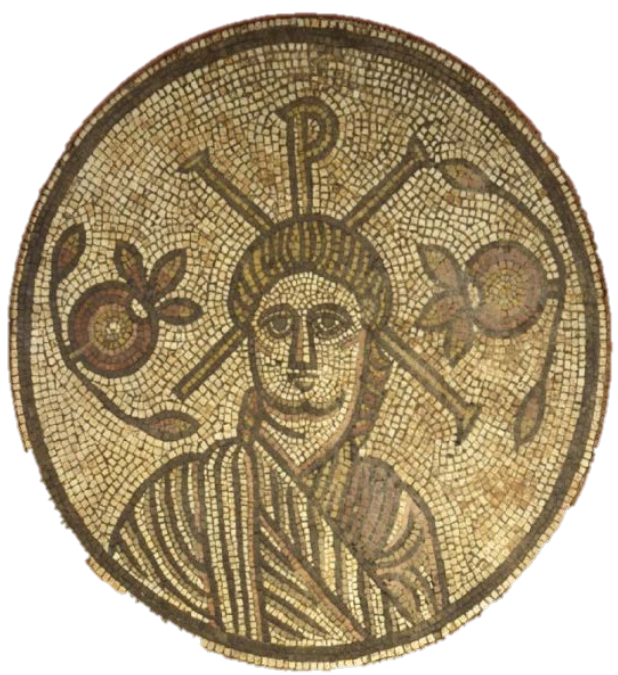

Figure 1: Bust and Chi-Rho monogram from the Hinton St. Mary mosaic.
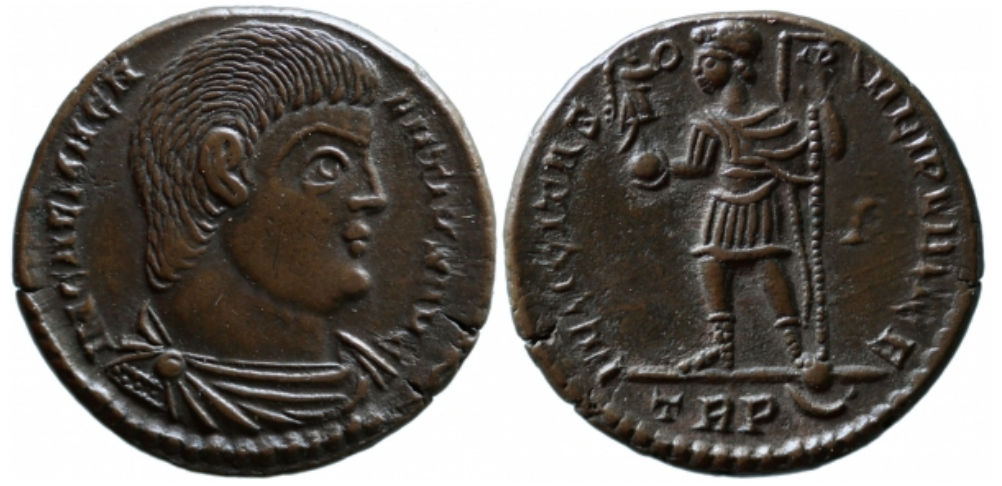

Figure 2: Bronze coin depicting Magnentius on the obverse side and a figure, likely Magnentius, holding a Chi-Rho monogrammed banner in his left hand, AD 350-353.
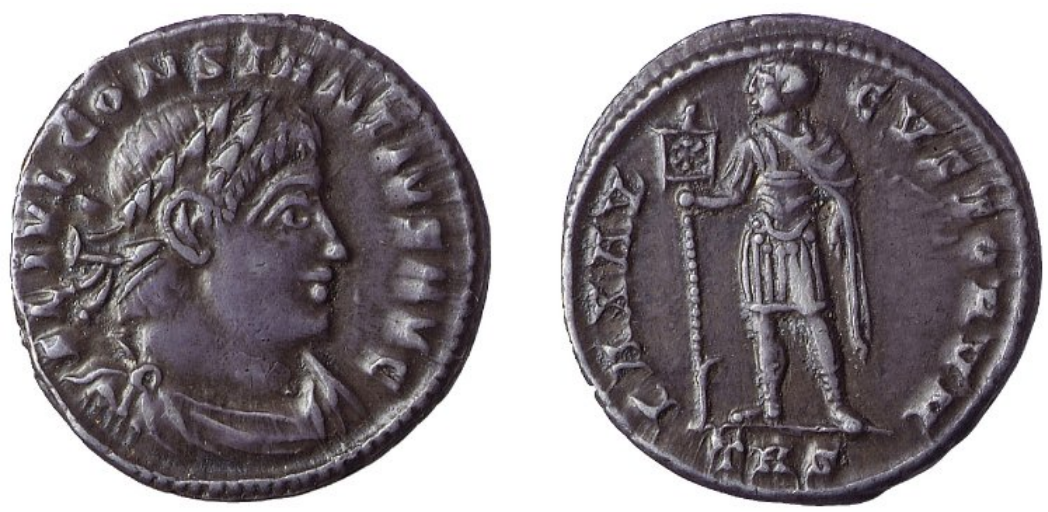

Figure 3: Silver coin depicting Constantine II on the obverse side and a figure, likely Constantine II, holding Chi-Rho monogrammed banner in his right hand, $A D$ 337-340. 
That the Chi-Rho featured in prominent locations in both the Frampton and Hinton St. Mary mosaics despite the ‘pagan’ imagery vastly outnumbering the ‘Christian’ imagery could, perhaps, be taken as another indication that these images were meant to reference the emperor as opposed to its literal Christian meaning. The Christ-like figure, as well, could then be a physical depiction of this emperor. Pearce furthers this point in her exploration of other depictions of Christ during this period. While the tunica and pallium are consistent with other Christ imagery, the style in which the facial features of the Hinton bust are depicted are not consistent with other images of Christ from the $4^{\text {th }}$ century. ${ }^{13}$ However, the large, well-defined, deep-set eyes, small lips, and geometric nose of the Hinton St. Mary mosaic is similar to the styles of the emperors depicted on their coinage, as displayed in Figures 2 and 3 above, as well as in sculpture and other art from the period. Even the clothing of the bust, while being clothing that other images of Christ share, are not solely worn by Christ in imagery. ${ }^{14}$

Having problematized the recognition of the Chi-Rho monogram as being only a Christian symbol, that the 'Christian' and pagan imagery are in close proximity on the same mosaics only serves to complicate their identifications further. Bellerophon’s appearance in these mosaics alongside ‘Christian’ imagery is not a singular phenomenon, though it is a combination that only seems to appear in Britain. ${ }^{15}$ This supposed Christ-Bellerophon commonality is often likened to the Christian adoption of the Orpheus myth in other archeological contexts as evidence of the 'Christianization’ of pagan iconography. 'Christianization’ would suggest a commonly seen pagan image being adopted and repurposed by early Christians to suit the Christian message. Many sources that discuss the Frampton or Hinton St. Mary mosaics also

\footnotetext{
13 Pearce, 202.

14 Pearce, 205.

15 Perring, “Gnosticism,” 107.
} 
reference the imagery of Orpheus in close context to the mosaics to argue that these mosaics are also examples of 'Christianized' pagan symbols. While the imagery of Orpheus and its significance to the topic of hybrid art is beyond the scope of this paper, it should be noted that the location of one of the most famous examples of Orpheus imagery, the Roman catacombs, contained a great deal of other archaeological finds to add to the analysis of the imagery as being Christian in context. This does not seem to be the case in Frampton and Hinton St. Mary. The assumption seems to be made that both Orpheus and Bellerophon serve the same purpose in 'Christian’ art as mythological figures that represent Christian allegories. However, beyond just the Bellerophon figure, the Frampton mosaics also depict Neptune, Bacchus, and several wind gods. ${ }^{16}$ Though 'pagan' in nature, these images have been explained through a Christian framework. The use of familiar pagan figures and stories could be representations of allegories, as previously stated, such as the depiction of Bellerophon slaying the chimaera serving as a representation of the Christian allegory of the triumph over death and evil. ${ }^{17}$ Similarly, the animal hunting scenes found in the Hinton St. Mary mosaics can be seen to showcase the natural world as created by the Christian god, with the Bible providing context to this use of allegories and the natural world. ${ }^{18}$ However, as the only 'biblical' depiction in these mosaics are the ChiRho monograms indicating 'Christ' and a maybe-Christ figure, the argument of using the Bible as a framework in which to view the rest of the pagan imagery lacks substance. That the Chi-Rho provides the only reference to Christianity in the mosaics, and that this monogram may be used as a reference to the emperor rather than a recognition of the Christian religion, serves to further destabilize the interpretation of all pagan imagery present in the mosaics as mere allegories.

\footnotetext{
${ }^{16}$ Dunbabin, Mosaics, 95.

17 Scott, Art and Society, 155.

18 Scott, Art and Society, 155-156.
} 
However, the use of pagan figures in Christian contexts as allegories or supporting identifiably Christian themes cannot be entirely dismissed, as Bellerophon appears in other associations with supposedly-Christian imagery and, as previously stated, other pagan myths like Orpheus are also repeatedly seen in Christian contexts, and while Bellerophon and Orpheus cannot be undeniably linked, it cannot be confidently separated, either. However, the prominence and large number of pagan figures depicted in the mosaics of Hinton St. Mary and Frampton are too significant to dismiss as merely supporting Christian allegories, especially if the Christian Bible and its moral messages are the foundation upon which the interpretations are justified despite the altogether lack of biblical stories depicted in the mosaics.

An alternative interpretation of the St. Mary and Frampton mosaics are, rather than representing the 'Christianization' of pagan themes, the "essential paganism of a lightly held Christianity." ${ }^{\prime 19}$ In this interpretation, the pagan deities become significant figures rather than allegories, and the Chi-Rho monogram could be seen as either an inclusion of Christian imagery as a co-existing state with pagan art or as an acknowledgement of the Chi-Rho as the Emperor's standard. ${ }^{20}$ Perring draws on the writings of anti-heretics, who criticized Christian heretics for the exploitation of pagan imagery and concepts. ${ }^{21}$ The lavishness of and the attention to detail put into mosaics within grand villas also makes it unlikely that, according to Perring, the inclusion of pagan imagery was due to a mere lack of understanding or ignorance of what the figures represented. They should, therefore, be considered a cognisant choice. ${ }^{22}$ This interpretation of the Hinton St. Mary and Frampton mosaics depicts the amalgamation of both Christianity and pagan imagery as a representation of the amalgamation of Christian and pagan

\footnotetext{
${ }^{19}$ Perring, “Gnosticism,” 102.

${ }^{20}$ Perring, 102.

${ }^{21}$ Perring, 102.

22 Perring, 103.
} 
beliefs and practices, condemned as heresy by the Christians. The prominence of the Chi-Rho, whether included as an embrace of Christ or as an acknowledgement to the emperor, and the quantity of pagan figures creates difficulty in identifying one element or the other as the ‘emphasized’ religion.

The discourse surrounding the mosaics often focuses on the figures depicted and how they may be interpreted, but the remaining imagery, particularly the hunting and nature scenes of the Hinton St. Mary mosaic, are either left unmentioned or grouped into either supporting the ‘pagan’ imagery or celebrated a Christian-god-created nature. However, despite no consensus having been reached by scholars regarding the function of the physical buildings that housed the mosaics, the location of the estate in the north of Britain should not be ignored as a potential source for interpreting the imagery. Katherine Dunbabin argues for the inclusion of such imagery not necessarily for its indication of any particular significant religious meaning but rather for its commonality and fashionable nature during the time the mosaic was created. The hunting and animal scenes, as well as the fruit-bearing tree, could be, she argues, merely images that relate to the fertility of the earth and prosperity of the estate itself, rather than a deeper representation of Christian ideals and allegories. ${ }^{23}$

As evidenced by the contradictory scholarship surrounding this topic, the ability to identify artwork as solely 'Christian’ or 'pagan' is a problematic task. A great deal of scholarship argues for the interpretation of these Christian/pagan images as evidence of the 'Christianization' of pagan symbols. However, these interpretations may either de-emphasize or negate entirely the significance of these pagan images, even as these mythological figures outnumber the quantity of Christian imagery. Though Christianity is a more recent religion, the assumption that it was only

${ }^{23}$ Dunbabin, Mosaics, 96. 
Christianity that adopted the traditional pagan imagery (and that any imagery that references Christianity must be entirely Christian in nature) suggests that pagans were uninfluenced by the Christian religion, which we know is an incorrect claim. The existence of anti-heretical writings from this time provides evidence to the hybridity of Christian and pagan beliefs and imagery, and suggests that the combination of these imageries was not only a vehicle for Christian allegories but also serves as a possible representation of the 'heretic' adaption and practice of both pagan and Christian religions. The tendency towards categorizing these images as either pagan or Christian ignores any existence of hybrid religious practices, practices which are known to exist as Christians of the time not only branded these groups with the term 'heretics' but wrote extensively on the subject. ${ }^{24}$ While the existence of a hybrid pagan-Christian worship does not prove that the Frampton and Hinton St. Mary mosaics are not Christian in nature, it does disrupt some of the academic assumptions that the Chi-Rho, the central figure, and all of the surrounding imagery can only suggest a message of Christianity and nothing else. While scholarship on this topic mostly assumes the Chi-Rho to be immediately indicative of a Christian household, it may also be possible that these mosaics do not actually employ any Christian imagery, or at least do not employ them as a promotion of Christianity or an indication of a belief of the Christian god. Pearce's article on the mosaics provided a strong example of challenging the assumptions made by other scholars about what 'Christian’ art entails. However, despite Pearce’s strong arguments, that the Chi-Rho is a Christian symbol and that the central figure of the Hinton St. Mary mosaic does wear the tunica and pallium worn by other images of Christ also suggests that the possibility of a Christian significance cannot be entirely dismissed, either. If the occupants of these buildings did employ these images as an expression of religious belief rather than just

\footnotetext{
${ }^{24}$ Perring, “Gnosticism,” 107.
} 
'fashionable' imagery as Dunbabin mentions, then just as the so-called heretics written about in length by the Christians of this time adopted both pagan and Christian practices in their religious activities, the hybrid imagery may not be an indication of one religion or the other being the only religion practiced, but rather a representation of the hybrid belief systems practiced by an empire in the beginnings of a pagan-dominated shift to Christianity. 
Dunbabin, Katherine M.D., Mosaics of the Greek and Roman World. Cambridge: Cambridge University Press, 1999.

Ling, Roger. Ancient Mosaics. London: British Museum Press, 1998.

Pearce, Susan. "The Hinton St Mary Mosaic Pavement: Christ or Emperor?" Britannia 39 (2008): 193-218.

Perring, Dominic. “Gnosticism' in Fourth-Century Britain: The Frampton Mosaics Reconsidered.” Britannia 34 (2003), 97-127.

Scott, Sarah. Art and Society in Fourth-Century Britain: Villa Mosaics in Context. Oxford: Oxford University School of Archaeology, 2000.

Thomas, Charles, Christianity in Roman Britain to AD 500. London: Batsford Academic and Educational LTD, 1981. 